\title{
A comparative study on implementation of aesthetics education in selected government and private school in debremarkos town
}

\author{
Atalay Mesfin Anteneh ${ }^{1}$, Bekele Wubshete ${ }^{2}$ \\ ${ }^{1}$ Debremarkos College of teachers' education, Aesthetics and physical education Department, Pobox-428 Debremarkos, Ethiopia \\ ${ }^{2}$ Debremarkos college of teacher education, Debremarkos, Ethiopia
}

\section{Email address:}

atalaymusic@gmail.com (A. M. Anteneh),bekelewubshet@gmail.com (B. Wubshete)

\section{To cite this article:}

Atalay Mesfin Anteneh, Bekele Wubshete. A Comparative Study on Implementation of Aesthetics Education in Selected Government and Private School in Debremarkos Town. Education Journal. Vol. 3, No. 1, 2014, pp. 15-23. doi: 10.11648/j.edu.20140301.13

\begin{abstract}
The purpose of this study was to investigate the possible factors affecting implementation of aesthetics education in government and private school in Debremarkos town. Facility conditions and school outcomes such as student academic achievement, attendance, interest, completion of given period and teacher information about aesthetics. School facility condition for the implementation of aesthetics in the schools was determined by the interest of students, lack of materials and information gap. Through the use of four different research instruments, the ultimate goal of this study was to ensure the factors affecting implementation of aesthetics education in selected school. Through the use of students' questionnaire, are provided some insights into the teachers' real practices and their preferences of teaching aesthetics education in the school. It is also clear that most of problem is shared in teachers, students and administrative bodies. Regarding when should teachers teach aesthetics education they want to let students to play in the field? The marking strategy teachers' use was also in problem of recording in their school because of sometimes they divided aesthetics marks for other subjects. Aesthetics education is no doubt a vital component in teaching any subjects easily and developing adequate children education proficiency. However, in different schools aesthetics education is not given depending on the curriculum designed by ministry of education. Depending on the data gathered from students and teachers using questionnaire interview and document analysis we concluded that schools haven't enough aesthetics education teachers, aesthetics teachers have information gap, teachers were not teaching depending on the curriculum, there are lack of Music and Art material in the school, the school director don't follow up ,teachers don't take attendance in the period of aesthetics and the let students to play in the field. The researchers recommendations based upon this study include the following: The school, Debremarkos in the school, Amahara regional education office and ten concerned college should increase the enrolments of aesthetics teachers, College teachers should increase their relation with them to solve the problem, School director and other concerned body should follow up the implementation depending on the education office and Amahara regional education office should better to full fill the instruments designed curriculum and the criteria that the college uses to select students should be depending on practical aspects.
\end{abstract}

Keywords: Music Education, Aesthetics, Art Education

\section{Introduction}

\subsection{Background of the Study}

Ethiopia is one of the ongoing developing countries in east Africa which has different administrative zones and regional states. Amahara regional state is one of the regional states in the Federal Democratic Republic of Ethiopia. It is located in the north western part of the country between 9-20-140 North latitude and 36-20-40-20 east longitude. The region comprises $15.3 \%$ the country's territory (yassin Ahmed 1997) East Gojjam Administrate Zone is one of the 11 administrate zone. Which consists of 18 wereda One of the member wereda is Debere markos city administration. In this city administration there are so many elementary schools. However the specific area of this research focus on selected four governmental and two private schools. Teaching Aesthetics education is a complex and difficult task. One of the most complex and difficult tasks in the filled of education is to produces active and 
artistic citizen. Aesthetics education has its own power to cultivate such citizens. There are so many factors that get involved the production of committed and responsible professionals throughout the country.Since Aesthetics education included music and art it is imitation there is a feature of both Plato's Theories of course he was not the $1^{\text {st }}$ or the last person to think that art imitates reality. The idea was still strong in the renaissance, when Vasari, in his lives of the painter Saied that painting is the imitation of all living thing of nature with their colors and designs just they are in nature "It may still be the most commonly held theories. Most people still think that a picture must be picture of something and that an artist is someone who can make a picture that' looks Just like the real thing. It was not until date in the 19thc that the idea of art as imitation. Depending on the above limitation I have initiated to conduct this research

\subsection{Statement of the Problem}

Nowadays, Aesthetics education becomes one of the popular subjects in the world as well in our country, different universities take responsibilities to give training and its function is tremendous in the development of the country. Because of such reason Aesthetics education became a separate subject from grade five through grade eight having its own curriculum for elementary schools. But considerable problem arose in the teaching learning process of the subject matter. But stockholders are not seen while exploiting the benefits of art education partly because in numerable problems encounter the implementation of Art education Thus, initiated identify the factors and to suggest possible solutions from the findings. Depending on these the researcher posed the following key questions

$>\quad$ What are the major factors that hinder teachers and students in teaching/learning Aesthetics education?

$>$ Do teachers attitude affect the teaching/learning process of Aesthetics education?

$>$ To what extent Aesthetics education is effectively given in elementary school?

$>$ Do students have lack of interest towards aesthetics?

\subsection{Objective of the Study}

The purpose of this study will be to identify the factors that hinder effective implementation of Aesthetics education and suggest possible solution for the problem

The specific objectives of this study are:-

$>$ To identify the factors that hinder teaching Aesthetics education in four governmental and two private schools in Deberemarkos town.

$>$ To suggest measures and actions regarding the problem to Aesthetics education teachers to indicate appropriate solution.

$>$ To increase the participation of concerned bodies in problem solving.

$>$ To identify to what extent Aesthetics education implement effectively?

\subsection{Significance of the Study}

When this study identifies weather Aesthetics education implement based on the curriculum or not will be investigated.

Therefore, the schools and werda Aesthetics education teachers can teach by avoiding the problem. In this case not only the teachers but also students and parents are satisfied. Research results usually solve some problems, or at least, they reveal the existence of a problem. As this research attempts to find out what reason affect the implementation of aesthetics education in elementary schools, the result of this study had the following importance.

1. As aesthetics is an important subject including skills which students should develop, this research helps teachers and students to choose or use aright methods which promote effective teaching-learning of aesthetics education.

2. It will help teachers to give aesthetics education based on the designed curriculum.

3. It can also be useful to other interested bodies as an indicator for further research.

\subsection{Delimitation of the Study}

There are different forms of aesthetics education given in different levels like in the teachers college and TVET schools. To manage the study appropriately, this research was on selected elementary schools' In addition, the problem of this study may be the problem of many schools, but it was difficult to manage all schools in the study. So this research focused on few schools in the ketema wareda /city administration, namely./ Dibza elementary schools, T/Haymanot elementary Schools, Endemata elementary Schools and Abima elementary schools form governmental schools. Sintayehu and Hoheyate elementary schools From private schools. These three schools are selected by lottery method. When we select by using the lottery method we use the following steps let $\mathrm{N}=$ number of all schools in the town and $n=$ sample schools then,

1. we assign numbers from $1-\mathrm{N}$

2. Write numbers on prepare tickets or piece of paper.

3. Wrap the tickets.

4. Take out n number of tickets randomly, and then the numbers of the population who contain the numbers drawn were samples for the study.

\subsection{Limitations}

1. Findings from this study may not be generalized beyond the selected schools

2. Only identified six schools administrators at selected Debremarkos elementary schools. then only $30 \%$ of the schools covered.

3. Objectivity of the responses to the survey instrument may have been affected by personal biases of the school teachers completing the instrument.

4. It is impossible to identify all variables impacting student affecting implementation of Aesthetics education. 
5. The research may have a problem of biased observation since we the researchers are two in number.

\subsection{Operational Definition of Terms}

Aesthetics education $=$ music and Art given to fifth and sixth grades in elementary school.

Governmental schools=Elementary schools which run their work by government budget.

Private schools $=$ Elementary schools which is run their work by their own.

Binding agent $=$ all rounded subject which used as a joint for many subjects.

\section{Methodology of the Study}

The study is concerned on the factors affecting the implementation of Aesthetics education in the selected schools in Debremarkos town in 2011/2012

\subsection{Participants of the Study}

When this research will be conducted the main data sources are Aesthetics education teachers of the selected elementary schools, students and the researches will use previous documents and results of students.

\subsection{Sampling Techniques and Sample Size of the Study}

The subjects of this study are eleven Aesthetics education teachers and 48 students in all selected schools because of time shortage. The selected schools the researcher selected two class in each schools. The researcher took purposive sampling to find deep information about the factors which affect implementation of Aesthetics education in selected schools.

\subsection{Method of Data Collection and Procedures}

\subsubsection{Data Collecting Tools}

The researchers use three kinds of instruments. The first one is questioner in which different question will be prepared, distributed, collected and analyzed. The second and third types of data collecting tools are interviewing and observation. The questioner are two types the first one is closed ended and the second one is open ended that gives a chance for the participants to write their feelings freely.

\subsubsection{Procedures of Data Collection}

First the researcher prepare questioner for the students by using Amharic since students of this grade level may not understand the English question, but for Aesthetics education teachers of the schools' questioner prepared by English language.

Then the entire questioner will be distributed and collected by the researchers when the study will take place. The data was collected from six sample schools.

\subsection{Data Analysis Techniques}

After the data collected from the participants of this study the researchers use the following methods of data analysis

A/Narration method of data analysis and interpretation from the qualitative and

B/ Percentage method from the quantitative method. This all the listed methods of data analysis was used depending on the data obtained from the participants.

\section{Data Analysis and Interpretations}

This chapter presents descriptions and explanations of the findings driven by the research questions of this study of the relation of factors affecting implementation of aesthetics education in the selected elementary school of Debremarkos city administration.

\subsection{Results of Teachers' Questionnaires}

The sample teachers' have given responses by answering agree, disagree, strongly disagree, strongly agree and undecided for fifteen closed ended and eighteen openended questions. Depending on the data collected from the participants it is analyzed as follows

Table 1. Teachers response implementation and Student Attendance

\begin{tabular}{|c|c|c|c|c|c|c|c|c|c|c|c|}
\hline \multirow{2}{*}{ No } & \multirow{2}{*}{ Item } & \multicolumn{2}{|c|}{$\begin{array}{l}\text { strongly } \\
\text { disagree }\end{array}$} & \multicolumn{2}{|c|}{ disagree } & \multicolumn{2}{|l|}{ agree } & \multicolumn{2}{|c|}{ strongly agree } & \multicolumn{2}{|c|}{ undecided } \\
\hline & & In No & In $\%$ & In No & In $\%$ & In No & In $\%$ & In No & In $\%$ & In No & In \% \\
\hline 1 & $\begin{array}{l}\text { I you follow up implementation of } \\
\text { Aesthetics education? Even } \\
\text { recording attendance? }\end{array}$ & $\mathbf{0}$ & $\mathbf{0}$ & 11 & 100 & $\mathbf{0}$ & $\mathbf{0}$ & $\mathbf{0}$ & $\mathbf{0}$ & 0 & $\mathbf{0}$ \\
\hline
\end{tabular}

As we can be seen in table 1 above, teachers were asked whether they follow up implementation of Aesthetics education or not. Accordingly, regarding this item, all of the respondents, that is 11 Teachers $(100 \%)$ said 'disagree' while none of the teachers replied the rest alternatives. Therefore, from this we can understand that aesthetics teachers weren't given attention to the implementation of Aesthetics education in their school.

As Sharer (1983) put aesthetics need the follow up of the subject teacher's unless it will not be grown then lack of following up from the subject teachers affect the implementation of aesthetics education. 
Student attendance has long been linked to success in school. Therefore, it stands to reason that educational leaders and policy makers would be interested in the physical Conditions that contribute to absenteeism (Lyons, 2002). Then in the selected school most of the time more than half students weren't presented due to lack of attendance in the period of aesthetics education.

Depending on table 2 in the school there are curriculums of aesthetics education, but $10(90.9 \%)$ of teachers have a problem of relating aesthetics education to the curriculum of Aesthetics education designed by ministry of education, problem of relating with its curriculum and lack of knowledge about its importance for children. Aesthetics education (Lipman 1974; Lipman \& Sharp 1978; Lipman, Sharp \& Oscanyan 1980; Reed 1989). There are extensive teacher's manuals that accompany each text, filled with discussion ideas, exercises, and activities but teachers have a problem of relating each material with the curriculum because of Aesthetics is abroad concept. The

Table 2. Relating art education to Aesthetics education, curriculum and importance of aesthetics for children.

\begin{tabular}{|c|c|c|c|c|c|c|c|c|c|c|c|}
\hline \multirow{2}{*}{$\begin{array}{l}\mathbf{N} \\
\mathbf{0}\end{array}$} & \multirow[t]{2}{*}{ Item } & \multicolumn{2}{|c|}{$\begin{array}{l}\text { strongly } \\
\text { disagree }\end{array}$} & \multicolumn{2}{|c|}{ disagree } & \multicolumn{2}{|l|}{ agree } & \multicolumn{2}{|c|}{ strongly agree } & \multicolumn{2}{|c|}{ undecided } \\
\hline & & In No & In $\%$ & In No & In $\%$ & In No & In $\%$ & $\begin{array}{l}\text { In } \\
\text { No }\end{array}$ & In $\%$ & In No & $\begin{array}{l}\text { In } \\
\%\end{array}$ \\
\hline 1 & $\begin{array}{l}\text { I have not a problem of relating art } \\
\text { education to Aesthetics education. }\end{array}$ & 10 & 90.9 & 1 & 9.09 & 0 & 0 & 0 & 0 & 0 & $\mathbf{0}$ \\
\hline 2 & $\begin{array}{l}\text { I implement aesthetics education depending } \\
\text { on its curriculum. }\end{array}$ & 10 & 90.9 & 1 & 9.09 & 0 & 0 & 0 & 0 & 0 & $\mathbf{0}$ \\
\hline 3 & $\begin{array}{l}\text { I know the importance of aesthetics } \\
\text { education for children. }\end{array}$ & 0 & $\mathbf{0}$ & $\mathbf{0}$ & $\mathbf{0}$ & 10 & 90.9 & 1 & 9.09 & $\mathbf{0}$ & $\mathbf{0}$ \\
\hline
\end{tabular}

teachers who teach in the selected schools have a great problem with relating aesthetics education with that of the curriculum designed by ministry of education. The second huge problem as table 2,10 teachers $(90.9 \%)$ respond that most teachers believed that aesthetics is important for children but really they think aesthetics is a subject for play but they have a big gap in the importance of aesthetics for the future life of students in elementary level. Since in our observation they let them to play rather they learn properly.

Table 3. Information gap and School Facilities

\begin{tabular}{|c|c|c|c|c|c|c|c|c|c|c|c|}
\hline \multirow{2}{*}{ No } & \multirow{2}{*}{ Item } & \multicolumn{2}{|c|}{ strongly disagree } & \multicolumn{2}{|c|}{ disagree } & \multicolumn{2}{|c|}{ agree } & \multicolumn{2}{|c|}{ strongly agree } & \multicolumn{2}{|c|}{ undecided } \\
\hline & & $\begin{array}{l}\text { In } \\
\text { No }\end{array}$ & In \% & $\begin{array}{l}\text { In } \\
\text { No }\end{array}$ & In \% & $\begin{array}{l}\text { In } \\
\text { No }\end{array}$ & In \% & $\begin{array}{l}\text { In } \\
\text { No }\end{array}$ & In $\%$ & In No & In $\%$ \\
\hline 1 & $\begin{array}{l}\text { I have no information gap about } \\
\text { Aesthetics education }\end{array}$ & 4 & 36.36 & 7 & 63.63 & 0 & 0 & 0 & 0 & 0 & $\mathbf{0}$ \\
\hline 2 & $\begin{array}{l}\text { The condition of the school is comfortable } \\
\text { to teach aesthetics education. }\end{array}$ & 11 & 100 & 0 & 0 & 0 & 0 & 0 & 0 & 0 & $\mathbf{0}$ \\
\hline 3 & $\begin{array}{l}\text { There are enough music and art } \\
\text { instruments in the school. }\end{array}$ & 11 & 100 & 0 & $\mathbf{0}$ & 0 & 0 & 0 & 0 & 0 & $\mathbf{0}$ \\
\hline
\end{tabular}

As we have seen in table 3, 36.36\% of teachers strongly disagree and $63.63 \%$ of teachers said that disagree then if we add strongly disagree and disagree $100 \%$ of teachers have information gap abut aesthetics education then it has a significant impact upon teacher performance (Christopher, 1991).Factors, such as information gap, working conditions, which improve teacher job satisfaction, have been Found to have a direct impact upon school effectiveness.

In the second item no $2100 \%$ of teachers respond that the school condition is not comfortable to teach aesthetics education. As (O’Neill, 2000). Fisher and Grady (1998) found that poor facility conditions were a profound factor in teacher job dissatisfaction. Then aesthetics teachers are not interested to teach without any facilities or instruments.In item $\mathrm{n} 3$, all teachers respond that no instruments are found in the school so it also affects the implementation of aesthetics education in elementary school since "Learning is a complex activity that puts students' motivation and physical Condition to the test" (Lyons, 2002, p. 10). It has been a long-held assumption that curriculum and teaching have an impact on learning. However, it is becoming more apparent that the physical condition of our schools can influence student achievement. Earthman, Cash and Van Berkum (1996) recently found that fifth and sixth grade students are in low standard buildings scored low as measured by the Comprehensive Test of Basic Skills than did their counterparts attending class in substandard facilities. So the school condition wasn't comfortable to teach aesthetics properly because of no instruments in the school. 
Table 4. Attitude of community towards aesthetics, number of professionals and problem of taking Aesthetic judgment.

\begin{tabular}{|c|c|c|c|c|c|c|c|c|c|c|c|}
\hline \multirow{2}{*}{ No } & \multirow[t]{2}{*}{ Item } & \multicolumn{2}{|c|}{ strongly disagree } & \multicolumn{2}{|c|}{ disagree } & \multicolumn{2}{|c|}{ agree } & \multicolumn{2}{|c|}{ strongly agree } & \multicolumn{2}{|c|}{$\begin{array}{l}\text { undecide } \\
\text { d }\end{array}$} \\
\hline & & $\begin{array}{l}\text { In } \\
\text { No }\end{array}$ & In $\%$ & $\begin{array}{l}\text { In } \\
\text { No }\end{array}$ & In $\%$ & $\begin{array}{l}\text { In } \\
\text { No }\end{array}$ & In $\%$ & $\begin{array}{l}\text { In } \\
\text { No }\end{array}$ & In $\%$ & $\begin{array}{l}\text { In } \\
\text { No }\end{array}$ & $\begin{array}{l}\text { In } \\
\%\end{array}$ \\
\hline 1 & $\begin{array}{l}\text { The school community gives emphasis to } \\
\text { aesthetics like other subjects. }\end{array}$ & 2 & 18.18 & 8 & 72.72 & 1 & 9.09 & 0 & 0 & 0 & $\mathbf{0}$ \\
\hline 2 & $\begin{array}{l}\text { Aesthetics in our school is given by } \\
\text { professionals. }\end{array}$ & 1 & 9.09 & 2 & 18.18 & 5 & 45.45 & 3 & 27.27 & 0 & $\mathbf{0}$ \\
\hline 3 & $\begin{array}{l}\text { Teacher in our school have Problem of taking } \\
\text { Aesthetic judgment. }\end{array}$ & $\mathbf{0}$ & $\mathbf{0}$ & $\mathbf{0}$ & $\mathbf{0}$ & 3 & 27.27 & 8 & 72.72 & $\mathbf{0}$ & $\mathbf{0}$ \\
\hline
\end{tabular}

As we have seen in table 4 , in item no 1 about the emphasis of school community towards aesthetics education comparing with other subjects 2(18.18\%)of the participants strongly disagree and $72.72 \%$ of respondents disagree then we should grasped that the school community have their own negative impact towards the implementation of aesthetics education in the selected elementary school. Whereas in item no 2 and 3 the information obtained from the participants shows in some schools aesthetics is given by professionals but the other said that rather than giving aesthetics by professionals they assign teachers who is drunker and weak in teaching other subjects.

Table 5. Interests of teachers, students and thinking about aesthetics.

\begin{tabular}{|c|c|c|c|c|c|c|c|c|c|c|c|}
\hline \multirow{2}{*}{ No } & \multirow{2}{*}{ Item } & \multicolumn{2}{|c|}{ strongly disagree } & \multicolumn{2}{|c|}{ disagree } & \multicolumn{2}{|l|}{ agree } & \multicolumn{2}{|c|}{ strongly agree } & \multicolumn{2}{|c|}{ undecided } \\
\hline & & $\begin{array}{l}\text { In } \\
\text { No }\end{array}$ & In $\%$ & $\begin{array}{l}\text { In } \\
\text { No }\end{array}$ & In $\%$ & In No & In $\%$ & $\begin{array}{l}\text { In } \\
\text { No }\end{array}$ & In $\%$ & $\begin{array}{l}\text { In } \\
\text { No }\end{array}$ & $\begin{array}{l}\text { In } \\
\%\end{array}$ \\
\hline 1 & $\begin{array}{l}\text { I teach aesthetics since I am } \\
\text { interested to teach. }\end{array}$ & 2 & 18.18 & 1 & 9.09 & 5 & 45.45 & 3 & 27.27 & 0 & $\mathbf{0}$ \\
\hline 2 & $\begin{array}{l}\text { Students are interested to learn } \\
\text { aesthetics depending on its } \\
\text { importance. }\end{array}$ & 5 & 45.45 & 3 & 27.27 & 2 & 18.18 & 1 & 9.09 & 0 & $\mathbf{0}$ \\
\hline 3 & Aesthetics is simple game to play. & 2 & 18.18 & 1 & 9.09 & 5 & 45.45 & 3 & 27.27 & $\mathbf{0}$ & $\mathbf{0}$ \\
\hline
\end{tabular}

In response to table No $5,45.45 \%$ teachers agree that they teach aesthetics depending on their interests and 3 $(27.27 \%)$ of them strongly agree then when we add most teachers teach by their interests but the rest teach aesthetics since that aesthetics is a simple play because $18.18 \%$ teachers replied 'disagree' and $9.09 \%$ strongly disagree. on the other hand, concerning item 2, majority of the students $(45.45 \%)$ explained that they sometimes Students are interested to learn aesthetics not depending on its importance because of they did not get the reason that why they learn aesthetics from their teacher. This shows that most of the time the teacher didn't give positive and constructive reason. Generally $28 \%$ ( disagree strongly disagree) believed that aesthetics is a simple game due to this they give little attention to the subject

Table 6. Number aesthetics teachers in our school and their need upgrade in art or music..

\begin{tabular}{|c|c|c|c|c|c|c|c|c|c|c|c|}
\hline \multirow{2}{*}{ No } & \multirow{2}{*}{ Item } & \multicolumn{2}{|c|}{ strongly disagree } & \multicolumn{2}{|c|}{ disagree } & \multicolumn{2}{|c|}{ agree } & \multicolumn{2}{|c|}{$\begin{array}{l}\text { strongly } \\
\text { agree }\end{array}$} & \multicolumn{2}{|c|}{ undecided } \\
\hline & & In No & In $\%$ & In No & In $\%$ & $\begin{array}{l}\text { In } \\
\text { No }\end{array}$ & In $\%$ & $\begin{array}{l}\text { In } \\
\text { No }\end{array}$ & In $\%$ & $\begin{array}{l}\text { In } \\
\text { No }\end{array}$ & $\begin{array}{l}\text { In } \\
\%\end{array}$ \\
\hline 1 & $\begin{array}{l}\text { There are enough aesthetics teachers in } \\
\text { our school. }\end{array}$ & 6 & 54.54 & 2 & 18.18 & 3 & 27.27 & 0 & 0 & 0 & $\mathbf{0}$ \\
\hline 2 & $\begin{array}{l}\text { I want to upgrade my skill in any of } \\
\text { art or music. }\end{array}$ & 11 & 100 & $\mathbf{0}$ & $\mathbf{0}$ & $\mathbf{0}$ & $\mathbf{0}$ & $\mathbf{0}$ & $\mathbf{0}$ & $\mathbf{0}$ & $\mathbf{0}$ \\
\hline
\end{tabular}

As table 6 shows that $54.54 \%+18.18 \%$ ( strongly disagree + disagree) there are no enough teachers in their schools. Then, if there are not enough teachers aesthetics should give by other non professionals. Where as in item no
2 in table 6 none of the respondents want to upgrade with Art or Music means have lack of interests to upgrade in the given subjects but they teach for the moment. 


\subsection{Responses Given for the Open Ended Questions, Observation and Interview.}

Most of the participants had given their feelings that the school hasn't musical or art instruments for training. The second point is that aesthetics education is not taken by professionals and most aesthetics teachers have lack of interests and information gap about aesthetics education. The third point obtained from the respondents are most teachers teach other subjects instead of aesthetics education period and other teacher use the period of aesthetics as afield simple play and the other implement out of the curriculum that designed by ministry of education. In some schools if lack of aesthetics teacher happen the subject is given for the weak or drunker teacher in the school.

In most schools teachers of aesthetics education teach two subjects with aesthetics then he/she teaches other subject in the period of aesthetics.

Most respondents said that it is simple to identify is it a period of aesthetics or not because if it is play it is period of aesthetics.

Generally not only other subject teachers but also aesthetics teachers have lack of attitudes to teach aesthetics education and lack of interests to upgrade in one of art or music this shows aesthetics education teachers are in problem of attitude and interests to teach it.

\subsubsection{Interview with Aesthetics Education Teachers}

According to our interview, Aesthetics education teachers said that implementation in their class and in the school was really a problem. They said that poor implementation of aesthetics affected them a lot because poor implementation meant that the learners did not understand the subject. So, they have to repeat the same lesson in the following day. This shows that, the attention of students towards aesthetics education is also low when they teach in the class but not in the fields.

The selected teachers said that both boys and girls were very poor in learning aesthetics education they said that some learners were too shy to share artistic thinking among the others. Another of aesthetics education teachers' explanations was that the problem was caused by lack of attention since it stops in grade $6^{\text {th. }}$ They also said that sometimes teachers could be the cause of the problem if we're not taught as depending on the allocated time. In addition to this they said that sometimes the method of teaching aesthetics can be the problem. Especially if the teacher is graduated by other field of study. On the other hand the attitude of administration staff also is negative as a result if lack of aesthetics teachers happens some drunker invite to teach aesthetics.In order to improve the situation the teachers had a number of suggestions. They said that slow learners should be given more/extra work to do in order to improve their learning in Aesthetics education because most of the time aesthetics education is full of skills. They added that they should encourage learning aesthetics education by their teachers especially when they are around the school ground and in their classrooms. This will help them to improve the subject; some teacher suggested that the use of teaching aids is also important in our lessons. They also added that the teacher should use different instruments. For example, doing some songs for learners to increase their interests. She suggested that teachers should have enough time to discuss problems with their learners.

In one private school teacher said that, the students learn aesthetics but the result isn't recorded rather it divided for all subjects as fulfillments of others. Instead of aesthetics education they recorded computer.

\subsubsection{Observations}

The focus of researcher observation was method of teaching that the teacher use, time spent in teaching Aesthetics education, and the interests of student's interaction between students and teachers activities performed out of the class room. When the researchers observe four periods of aesthetics education, the method of teaching was like other subjects means theoretical aspects but they cannot use practical way of teaching, teachers use the period of aesthetics for other subjects, students interest was good because of their teacher push them to play in the sports field the activities performed by the teachers out of the class was very amazing because rather than supporting students he perform his own work or he uses as a tea break.

\subsection{Results from the Student Respondents}

Table 7. interests of teachers in learning aesthetics

\begin{tabular}{|c|c|c|c|c|c|c|c|c|c|c|c|}
\hline \multirow{2}{*}{ No } & \multirow{2}{*}{ Item } & \multicolumn{2}{|c|}{ strongly disagree } & \multicolumn{2}{|c|}{ disagree } & \multicolumn{2}{|l|}{ agree } & \multicolumn{2}{|c|}{ strongly agree } & \multicolumn{2}{|c|}{ undecided } \\
\hline & & In No & In $\%$ & In No & In $\%$ & In No & In $\%$ & $\begin{array}{l}\text { In } \\
\text { No }\end{array}$ & In $\%$ & In No & In \% \\
\hline 1 & I like to learn aesthetics & 2 & 4.16 & 5 & 10.41 & 34 & 70.83 & 7 & 14.58 & 0 & $\mathbf{0}$ \\
\hline 2 & $\begin{array}{l}\text { I want to join to the university } \\
\text { in any of art or music. }\end{array}$ & 41 & 85.41 & 6 & 12.5 & 1 & 2.08 & $\mathbf{0}$ & $\mathbf{0}$ & $\mathbf{0}$ & $\mathbf{0}$ \\
\hline
\end{tabular}

In response to table No 7,84.88\% of the respondent students (agree + strongly agree) that they like to learn aesthetics education depending on their interests and the rest $15.22 \%$ of the students don't like learn aesthetics by different reasons. Then, when we compare the two most students are interested to learn but as we obtain during 
interview most students want to learn aesthetics because of that aesthetics is a simple play. We can conclude that they sometimes Students are interested to learn aesthetics not depending on its importance but they used as arrest. In item number 2 most students $97.46 \%$ don't want to join the university in any of music and art so it also strengthens that students want to learn aesthetics no depending on its important.

Table 8. number of teachers and interests of students

\begin{tabular}{|c|c|c|c|c|c|c|c|c|c|c|c|}
\hline \multirow{2}{*}{ No } & \multirow{2}{*}{ Item } & \multicolumn{2}{|c|}{ strongly disagree } & \multicolumn{2}{|c|}{ disagree } & \multicolumn{2}{|c|}{ agree } & \multicolumn{2}{|c|}{ strongly agree } & \multicolumn{2}{|c|}{ undecided } \\
\hline & & In No & In $\%$ & $\begin{array}{l}\text { In } \\
\text { No }\end{array}$ & In $\%$ & $\begin{array}{l}\text { In } \\
\text { No }\end{array}$ & In $\%$ & $\begin{array}{l}\text { In } \\
\text { No }\end{array}$ & In $\%$ & $\begin{array}{l}\text { In } \\
\text { No }\end{array}$ & In $\%$ \\
\hline 1 & $\begin{array}{l}\text { There are enough aesthetics teachers } \\
\text { in our school. }\end{array}$ & 20 & 41.66 & 8 & 16.66 & 16 & 33.33 & 4 & 8.33 & 0 & $\mathbf{0}$ \\
\hline 2 & I want to play music & 16 & 33.33 & 4 & 8.33 & 8 & 16.66 & 20 & 41.66 & $\mathbf{0}$ & $\mathbf{0}$ \\
\hline
\end{tabular}

As table 8 shows that $58.22 \%$ ( strongly disagree+ disagree) there are no enough teachers in their schools. Then, if there are not enough teachers, Aesthetics should give by other nonprofessionals. Where as in item no 2 in table $6,58.22 \%$ ( of the respondents said that they want to play music and exercising drawing in any where because of they consider as a simple game. $41.66 \%$ of the respondents don't want to play music as the researcher observe in the school and from their document all respondent of disagree and strongly disagee are cleaver students but not agree and strongly agree.

Table 9. attitudes of students towards their aesthetics teachers

\begin{tabular}{|c|c|c|c|c|c|c|c|c|c|c|c|}
\hline \multirow{2}{*}{ No } & \multirow{2}{*}{ Item } & \multicolumn{2}{|c|}{ strongly disagree } & \multicolumn{2}{|c|}{ disagree } & \multicolumn{2}{|c|}{ agree } & \multicolumn{2}{|c|}{ strongly agree } & \multicolumn{2}{|c|}{ undecided } \\
\hline & & In No & In $\%$ & In No & In $\%$ & $\begin{array}{l}\text { In } \\
\text { No }\end{array}$ & In $\%$ & $\begin{array}{l}\text { In } \\
\text { No }\end{array}$ & In $\%$ & $\begin{array}{l}\text { In } \\
\text { No }\end{array}$ & $\begin{array}{l}\text { In } \\
\%\end{array}$ \\
\hline 1 & $\begin{array}{l}\text { I like my aesthetics education } \\
\text { teacher because of letting to } \\
\text { play. }\end{array}$ & $\mathbf{0}$ & $\mathbf{0}$ & $\mathbf{0}$ & $\mathbf{0}$ & 26 & 54.16 & 22 & 45.84 & $\mathbf{0}$ & $\mathbf{0}$ \\
\hline
\end{tabular}

In response to table No 5,45.45\% teachers agree that they teach aesthetics depending on their interests and 3 $(27.27 \%)$ of them strongly agree then when we add most teachers teach by their interests but the rest teach aesthetics since that aesthetics is a simple play because $18.18 \%$ teachers replied 'disagree' and $9.09 \%$ strongly disagree. on the other hand, concerning item 2, majority of the students $(45.45 \%)$ explained that they sometimes Students are interested to learn aesthetics not depending on its importance because of they did not get the reason that why they learn aesthetics from their teacher. This shows that most of the time the teacher didn't give positive and constructive reason. Generally $28 \%$ ( disagree strongly disagree) believed that aesthetics is a simple game due to this they give little attention to the subject

\subsubsection{Interview with the Learners}

The learners whom I interviewed said that the problem was their parents who were not able to provide them to learn aesthetics education when they come to school. On this point the learners' reasons are very reasonable because parents have great impact in the students' performance and interests due to this learners will became slow learners and they will not enjoy learning.

When the researcher asked them do they liked to learn aesthetics education? they all said that they like subjects likes Math, English, and other subjects because they enjoyed looking at nice pictures and listening to some nice stories related with job opportunities.

The researchers also asked about their feelings when they were divided in groups for discussion. The learners said that they do not feel happy and free when put in to groups. The reason given was because some members of the group laughed at others when the y sing a song and this made them not contribute actively in the class.

The next question posed for the students were do you affected by the religion? Their answer was yes, and when we ask them why they said our religion is not invited to sing. Then we can conclude that their parents teach them about not learn aesthetics education. The other reason which is given by the students was that if someone sing and learn aesthetics education in their society $\mathrm{s} / \mathrm{he}$ is called Azemary then all students dislike this name.

\section{Recommendation}

The researchers have developed several conclusions based upon the data collection and analysis of this study. The following recommendations are based upon the results of this research and will hopefully guide other investigations as data is gathered and analyzed on this very important topic. 
The areas of implementation of aesthetics education and school facilities (musical and art instruments) were the two dependent factor that proved to have significant relationships to implement effectively then

$\checkmark \quad$ The school,Debremarkos education office and Amahara regional education office should better to full fill the instruments in the school.

$\checkmark$ According to the research data supplied in many schools there are lack of aesthetics education teachers so,

$\checkmark$ Amahara regional education office and ten concerned college should increase the enrolments of aesthetics teachers.

$\checkmark$ Elementary school aesthetics education teachers have information gap then to minimize this information gap,

$\checkmark \quad$ College teachers should increase their relation with them to solve the problem.

$\checkmark$ Most school teachers should not teach aesthetics depending on the curriculum so,

$\checkmark \quad$ School director and other concerned body should follow up the implementation depending on the designed curriculum.

$\checkmark \quad$ In one private school aesthetics marks of the students divided for other subjects then,

$\checkmark \quad$ Like Governmental schools Debremarkos city administration education office should follow up the activities of private schools.

$\checkmark$ Aesthetics education teachers should conduct research to change the present situation.

$\checkmark \quad$ The criteria that the college uses to select should be depending on practical aspects

\section{References}

[1] "A Oscar Wilde" by Richard Ellman p 159, pub Alfred A Knopf, INC. 1988

[2] A. Moles: Théorie de l'information et perception esthétique, Paris, Denoël, 1973 (Information Theory and aesthetical perception)

[3] Annemarie Gethmann-Siefert, Introduction to Aesthetics (Einführung in die Ästhetik), Munich, Wilhelm Fink, 1995, p. 7.

[4] Barnett Newman Foundation, Chronology, 1952 Retrieved August 30, 2010

[5] Bourdieu, Pierre (1984). Distinction. Routledge.

[6] Brian Massumi, Deleuze, Guattari and the Philosophy of Expression, CRCL, 24:3, 1997.

[7] Consider Clement Greenberg's arguments in "On Modernist Painting" (1961), reprinted in Aesthetics: A Reader in Philosophy of Arts.

[8] Datta, R.; Joshi, D.; Li, J.; Wang, J. (2006). "Studying aesthetics in photographic images using a computational approach". Europ. Conf. on Computer Vision. Springer.
[9] Davies, Penelope J.E. Denny, Walter B. Hofrichter, Frima Fox. Jacobs, Joseph. Roberts, Ann M. Simon, David L. Janson's History of Art, Prentice Hall; 2007, Upper Saddle River, New Jersey. Seventh Edition, pg. 277

[10] Derek Allan, Art and the Human Adventure, André Malraux's Theory of Art (Amsterdam: Rodopi, 2009)

[11] Derek Allan, Art and the Human Adventure: André Malraux's Theory of Art. (Amsterdam: Rodopi. 2009)

[12] Derek Allan. Art and the Human Adventure. André Malraux's Theory of Art. (Amsterdam: Rodopi, 2009)

[13] Dewey, John. (1932)'Ethics', with James Tufts. In: The Collected Works of John Dewey, 1882-1953 Edited Jo-Ann Boydston: Carbonsdale: Southern Illinois University Press.

[14] Freud, Sigmund, "The Uncanny" (1919). Standard Edition of the Complete Psychological Work of Sigmund Freud, 17:234-36. London: The Hogarth Press

[15] From the Literal to the Spiritual: The Development of the Prophet Muhammad's(s.a.w) Portrayal from 13th century Ilkhanid Miniatures to 17 th century Ottoman Art, Wijdan Ali, volume IV, issue 7, p. 1-24, 2001

[16] Green, Edward, "Donald Francis Tovey, Aesthetic Realism and the Need for a Philosophic Musicology," International Revue of the Aesthetics and Sociology of Music, 2005, p. 227.

[17] Guy Sircello, "How Is a Theory of the Sublime Possible?" The Journal of Aesthetics and Art Criticism Vol. 51, No. 4 (Autumn, 1993), pp. 541-550

[18] Guy Sircello, A New Theory of Beauty. Princeton Essays on the Arts, 1. Princeton, NJ: Princeton University Press, 1975.

[19] Guy Sircello, Love and Beauty. Princeton, NJ: Princeton University Press, 1989.

[20] Holm, Ivar (2006). Ideas and Beliefs in Architecture and Industrial design: How attitudes, orientations, and underlying assumptions shape the built environment. Oslo School of Architecture and Design..

[21] Immanuel Kant, The Critique of Judgment.

[22] J. Schmidhuber. Developmental robotics, optimal artificial curiosity, creativity, music, and the fine arts. Connection Science, 18(2):173-187, 2006

[23] J. Schmidhuber. Facial beauty and fractal geometry. Cogprint Archive: , 1998

[24] J. Schmidhuber. Low-complexity art. Leonardo, Journal of the International Society for the Arts, Sciences, and Technology, 30(2):97-103, 1997.

[25] J. Schmidhuber. Papers on the theory of beauty and lowcomplexity art since 1994 :

[26] 'Kalliphobia in Contemporary Art' in Art Journal v. 63 no. 2 (Summer 2004) p. 24-35

[27] Korsmeyer, Carolyn ed. Aesthetics: The Big Questions 1998

[28] Lacan, Jacques, The Ethics of Psychoanalysis (The Seminar of Jacques Lacan Book VII), NY: W. W. Norton \& Company, 1992. 
[29] Lyotard, Jean-Françoise, Scriptures: Diffracted Traces, in Theory, Culture and Society, Volume 21, Number 1, 2004.

[30] Massumi, Brian, (ed.), A Shock to Thought. Expression after Deleuze and Guattari. London \& NY: Routeledge, 2002.

[31] Merleau-Ponty, Maurice (1964), "The Visible and the Invisible". Northwestern University Press.

[32] Moshagen, M. \& Thielsch, M. T. (2010). Facets of visual aesthetics. In: Interrnational Journal .

[33] Page, James S. (2008) Peace Education: Exploring Ethical and Philosophical Foundations.

[34] Reber, R, Brun, M, Mitterndorfer, K: "The use of heuristics in intuitive mathematical judgment", Psychonomic Bulletin \& Review, 15(6):1174-1178

[35] Schmidhuber's theory of beauty and curiosity in a German TV show: http://www.br-online.de/bayerischesfernsehen/faszination-wissen/schoenheit--aesthetikwahrnehmung-ID1212005092828.xml

[36] Siegel, Eli, "Is Beauty the Making One of Opposites?", Journal of Aesthetics \& Art Criticism, 1955.
[37] The Abuse of Beauty: Aesthetics and the Concept of Art, By Arthur Coleman Danto, p.1, Published by Open Court Publishing, 2003, ISBN 0812695402, 9780812695403

[38] Why Beauty Is Truth: The History of Symmetry, Ian Stewart, 2008

[39] Wijdan Ali, (December 10, 1999,) The Arab Contribution to Islamic Art: From the Seventh to the Fifteenth Centuries, American Univ in Cairo Press,

[40] Wong, L.-K.; Low, K.-L. (2009). "Saliency-enhanced image aesthetic classification". Int. Conf. on Image Processing.

[41] Wu, Y.; Bauckhage, C.; Thurau, C. (2010). "The good, the bad, and the ugly: predicting aesthetic image labels". Int. Conf. on Pattern Recognition. IEEE. "Aesthetic Quality Inference Engine - Instant Impersonal Assessment of Photos". Penn State University. http://acquine.alipr.com. Retrieved 21 June 2009.

[42] Zangwill, Nick. "Aesthetic Judgment", Stanford Encyclopedia of Philosophy, 02-28-2003/10- 22-2007. Retrieved 07-24-2008. 